\title{
PROFIL SELF CONTROL MAHASISWA BIMBINGAN DAN KONSELING DALAM MENGATASI PROKRASTINASI AKADEMIK DI STKIP PGRI SUMATERA BARAT
}

\author{
Yogga Bristone ${ }^{1}$, Zulfikar $^{2}$, Septya Suarja ${ }^{3}$ \\ STKIP PGRI Sumatera Barat \\ yoggabristone@gmail.com
}

\begin{abstract}
The problem of this research is motivated by the existence of students who are less able to control themselves in the lecture process, there are students who like to procrastinate in completing lecture assignments, and students who like to be late in attending lecture classes. The purpose of this study is to describe: student self-control in overcoming academic procrastination in terms of the ability to control behavior, the ability to control the stimulus, the ability to anticipate an event or events, the ability to interpret events or events, and the ability to make decisions. quantitative descriptive The research population was 280 students.

The sampling technique used is simple random sampling. The number of samples in this study was 164 respondents. The instrument used is a questionnaire. Data analysis with interval scores. The results of this study revealed that in general students' self-control in overcoming academic procrastination was in the high category. Furthermore, it can be seen from the indicators: 1) ) Self control of students in overcoming academic procrastination based on indicators of ability to control behavior is in the high category, 2) Self control of students in overcoming academic procrastination based on indicators of ability to control stimulus is in the fairly high category, 3) Self control of students in overcoming academic procrastination based on indicators of the ability to anticipate an event or event is in the high category, 4) Self-control of students in overcoming academic procrastination based on indicators of ability to interpret events or events is in the high category, 5) Self-control of students in overcoming academic procrastination based on indicators of ability decision making is in the fairly high category. Based on the findings of this study, it is recommended for students to be able to further improve selfcontrol so that they are able to overcome academic procrastination in lectures.
\end{abstract}

Keywords : Self Control, Academic Procrastination

\begin{abstract}
ABSTRAK
Permasalahan penelitian ini dilatarbelakangi dengan masih adanya mahasiswa yang kurang dapat mengontrol dirinya dalam menjalani proses perkuliahan, adanya mahasiswa yang suka menunda dalam menyelesaikan tugas perkuliahan, dan mahasiswa yang suka terlambat dalam mengikuti kelas perkuliahan. Tujuan dari penelitian ini adalah untuk mendeskripsikan: self control mahasiswa dalam mengatasi prokrastinasi akademik dilihat dari aspek kemampuan mengontrol perilaku, kemampuan mengontrol stimulus, kemampuan mengantisipasi suatu peristiwa atu kejadian, kemampuan menafsikan peristiwa atau kejadian, dan kemampuan mengambil keputusan.Penelitian ini dilakukan dengan menggunakan metode deskriptif kuantitatif Populasi penelitian adalah 280 mahasiswa.

Teknik pengambilan sampel dengan menggunakan simple random sampling. Jumlah sampel dalam penelitian ini 164 orang responden. Instrumen yang digunakan berupa angket. Analisis data dengan skor interval. Hasil penelitian ini mengungkapkan secara umum self control mahasiswa dalam mengatasi prokrastinasi akademik berada pada kategori tinggi. Selanjutnya dilihat dari indikator: 1) ) Self control mahasiswa dalam mengatasi prokrastinasi akademik berdasarkan indikator kemampuan mengontrol perilaku berada pada kategori tinggi, 2) Self control mahasiswa dalam mengatasi
\end{abstract}


prokrastinasi akademik berdasarkan indikator kemampuan mengontrol stimulus berada pada kategori cukup tinggi, 3) Self control mahasiswa dalam mengatasi prokrastinasi akademik berdasarkan indikator kemampuan mengantisipasi suatu peristiwa atau kejadian berada pada kategori tinggi, 4) Self control mahasiswa dalam mengatasi prokrastinasi akademik berdasarkan indikator kemampuan menafsirkan peristiwa atau kejadian berada pada kategori tinggi, 5) Self control mahasiswa dalam mengatasi prokrastinasi akademik berdasarkan indikator kemampuan mengambil keputusan berada pada kategori cukup tinggi. Berdasarkan temuan penelitian ini direkomendasikan kepada mahasiswa agar dapat lebih meningkatkan self control sehingga mampu untuk mengatasi prokrastinasi akademik dalam perkuliahan.

Kata Kunci : Self Control, Prokrastinasi Akademik

\section{PENDAHULUAN}

Pendidikan merupakan suatu upaya yang dapat dilakukan untuk mengembangkan potensi diri yang berlangsung secara terus menerus dan menyesuaikan kebudayaan dan norma-norma yang diberlakukan masyarakat. Hal itu sesuai terhadap yang disampaikan Undang-undang Sistem Pendidikan Nasional No. 20 Tahun 2003 Pasal 1 Ayat 1.

Theodore Brameld (Anwar, 2015:123) mengatakan bahwa pendidikan adalah suatu kekuatan yang artinya memiliki otoritas yang cukup kuat bagi masyarakat yang memiliki kekuatan untuk menentukan dunia yang di inginkan dan bagaimana mewujudkannya. Pendidikan juga merupakan sebagai usaha untuk menumbuhkan dan mengembangkan potensipotensi bawaan, baik jasmani maupun rohani sesuai dengan nilai-nilai yang ada di masyarakat dan kebudayaan (Ansori, 2020:28).

Berdasarkan penjelasan di atas bahwa pendidikan merupakan sebuah usaha yang memiliki kewenangan yang kuat bagi masyarakat untuk dapat menciptakan suatu sistem yang mana itu dilakukan pendidik demi mencapai tujuan untuk mengembangkan kemampuan yang dimiliki pelajar dan juga untuk menciptakan masyarakat yang memiliki kebudayaan dan norma-norma yang mengarahkan kepada hal yang lebih baik demi mewujudkan dunia yang ideal.

Jenjang pendidikan yang terdapat di Indonesia diantaranya Sekolah Dasar menggunakan masa belajar 6 tahun, Sekolah Menengah Pertama dengan masa belajar 3 tahun, dan Sekolah Menengah Atas dengan masa belajar 3 tahun, yang lalu dapat melanjutkan studi ke Perguruan Tinggi. Pelajar yang melanjutkan ke Perguruan Tinggi dan Universitas telah mendapatkan predikat sebagai seorang Mahasiswa.

Mahasiswa merupakan kaum terpelajar yang memiliki peran penting dalam membangun perubahan yang berdampak baik bagi masyarakat dan lingkungannya. Untuk mencapai itu dibutuhkan ilmu pengetahuan yang diperoleh mahasiswa dalam mengikuti proses belajar. Belajar tidak hanya diperoleh di bangku perkuliahan, namun pula diperoleh melalui kegiatan yang bersifat diluar dari akademik ini berguna bagi mahasiswa tentunya agar dapat berpikiran kritis dalam menyatakan fakta dan realita yang ada. Mereka juga harus memiliki wawasan yang luas untuk mengatasi masalah atau kejadian yang berdampak signifikan terhadap perkembangan dan kemajuan bangsa dan negara.

Pada proses belajar mahasiswa di perguruan tinggi, banyak dari sebagian yang mengalami permasalah terkuhususnya masalah akademik, seperti metode belajar, pengumpulan tugas-tugas perkuliahan, manajemen waktu belajar, persiapan seperti ujian dan sebagainya. Jika mahasiswa tersebut mengalami kesulitan dalam menyelesaikan sesuatu hal sebelum batas yang telah ditentukan, seperti terlambat dalam mengumpulkan tugas-tugas perkuliahan, mengerjakan dan mempersiapkan sesuatu hal secara berlebihan, serta gagal dalam menyelesaikan tugas sesuai dengan batas pengumpulan yang telah ditentukan, maka dapat 
dikatakan mahasiswa tersebut telah melakukan perilaku prokrastinasi.

Prokrastinasi tergolong dalam istilah “ Procrastinate" yang berarti menunda. Ghufron 2003 (Ghufron dan Rini, 2010:150) menjelaskan bahwa prokrastinasi berasal dari adonan dua kata yaitu, "pro" yang berarti maju serta "crastinus" yang berarti hari esok, dan jika kedua kata tadi digabungkan akan memiliki arti yang kompleks yaitu penundaan yang dilakukan hingga hari esok. Seseorang yang memiliki kecenderungan menunda untuk memulai pekerjaan, saat menghadapi suatu pekerjaan dan tugas dianggap seseorang yang melakukan prokrastinasi. Tidak peduli apakah penundaan tersebut memiliki alasan atau tidak. Setiap penundaan pada saat menghadapi suatu tugas atau pekerjaan disebut prokrastinasi (Ghufron dan Rini, 2010:151).

Solomon dan Rothblum, (Balkis \& Duru, 2017:108) juga berpendapat bahwa prokrastinasi akademik merupakan sebagai suatu kesamaan individu buat menunda tugas-tugas akademik serta juga hampir selalu orang yang melakukan tindakan prokrastinasi dapat mengalami pengalaman kecemasan terhadap tugas akademik. Hal tadi terjadi karena adanya ketakutan terhadap kegagalan dan berpandangan bahwa segala sesuatu harus dilakukan dengan sahih.

Banyak juga ditemui mahasiswa yang sering melakukan penundaan dalam memulai untuk mengerjakan dan menyelesaikan tugas perkuliahannya, sebagaimana juga yang disampaikan oleh Aitken, (Endrianto, 2014:2) menyebutkan bahwa prokrastinasi merupakan penundaan pengerjaan tugas hingga mendekati batas waktu yang telah diberikan. Seseorang yang melakukan perilaku prokrastinasi ia mengetahui apa yang seharusnya dilakukan, namun tetap untuk tidak memilih melakukannya pada saat itu. Hal tersebut terjadi dikarenakan juga oleh rasa malas mahasiswa yang menganggap bahwa waktu dari pengumpulan tugas masih lama, jadi untuk apa membuat tugas sekarang sebab waktu pengumpulannya masih lama.
Sesuai penerangan dari beberapa ahli tadi bisa disimpulkan bahwa prokrastinasi akademik merupakan kegiatan penundaan terhadap suatu tugas atau tuntutan akademik yang dilakukan oleh seseorang yang didasari atas berbagai alasan maupun tanpa adanya alasan.

Perilaku prokrastinasi ini berkaitan sangat erat sekali dengan cara seseorang dalam mengendalikan diri. Sebagaimana juga disampaikan oleh Watson (Ghufron dan Rini, 2010:151) prokrastinasi berkaitan juga dengan perilaku untuk melawan kontrol. Sebagai pelajar, mahasiswa tentunya diharapkan agar dapat mengontrol diri dalam berbagai aktivitas guna untuk menunjang suatu pencapaian, terkhususnya pada segala aktivitas akademik ada di kampus.

Goldfried \& Merbaum (Ghufron dan Rini, 2010:22) mendefinisikan self control sebagai suatu kemampuan untuk menyusun, membimbing, mengatur, dan mengarahkan bentuk perilaku yang dapat membawa individu ke arah konsekuensi yang positif. Kontrol diri juga merupakan kemampuan untuk membimbing tingkah laku individu dalam menekan dan merintangi keinginan atau tingkah laku yang bersifat impulsive, Chaplin (Titisari, 2017:135).

Tangney, Boumeister \& Boone, (Ursia dkk, 2013:2) juga menjelaskan bahwa pelajar yang mempunyai self control yang baik akan lebih menonjol dalam peforma belajar seperti mengerjakan tugas atau prestasi akademik lainnya. Oleh karena itu, mahasiswa yang memiliki kontrol diri yang bagus akan menggunakan waktu dengan sebaik mungkin dalam mengerjakan tugas dan kebalikannya jika mahasiswa tersebut mempunyai self control yang lemah hal tersebut akan cenderung menimbulkan tingkah laku prokrastinasi akademik, jika hal ini terus dilakukan akan menimbulkan kebiasaan terhadap responnya dalam menghadapi tugas atau suatu pekerjaan.

Dalam kegiatan wawancara dan observasi yang dilakukan terhadap beberapa mahasiswa yang ada di STKIP PGRI Sumatera Barat khususnya pada program studi Bimbingan dan Konseling, adanya sebagaian besar mahasiswa 
yang mengalami hambatan dalam menjalani kegiatan belajar seperti mengabaikan tugas, kurang disiplin dan bosan sehingga tertidur dalam mengikuti proses belajar, tentunya ini akan sangat mempegaruhi dari hasil belajar yang mereka peroleh dalam satu semester. Selain itu, ternyata juga terdapat sebagian mahasiswa yang suka mengobrol dengan temannya, memainkan smartphone sewaktu perkuliahan, tidak fokus dalam memperhatikan dosen yang mengajar, mengedepankan aktivitas non akademik, tidak bisa mengatur waktu, dan sering keluar kelas dengan alasan permisi ke wc untuk buang air.

Berdasarkan uraian diatas bahwa masih banyak mahasiswa yang mengalami kendala dalam memenuhi tuntutan akademik di kampus. Hambatan-hambatan seperti rasa bosan dalam melakukan kegiatan belajar mengajar yang monoton, dangkalnya motivasi mahasiswa dalam mencapai keberhasilan akademik. Pada ujungnya mahasiswa tersebut akan kehilangan kendali diri dan akan menunda-nunda untuk memulai dalam menyelesaikan tugas akademik. Mahasiswa dengan perilaku yang suka menunda akan cenderung untuk lari dari tanggung jawab dan permasalahan sebagai bentuk perilaku dalam menghadapi hal yang tidak menyenangkan.

Berdasarkan dari uraian diatas prokrastinasi akademik juga terjadi pada mahasiswa program studi Bimbingan dan Konseling di STKIP PGRI Sumatera Barat, sehingga peneliti tertarik dalam melakukan penelitian ini untuk dikaji lebih mendalam. Penulis ingin mengetahui tentang bagaimana profil self control mahasiswa Bimbingan dan Konseling dalam mengatasi prokrastinasi akademik di STKIP PGRI Sumatera Barat.

\section{METODE PENELITIAN}

Penelitian ini telah dilakukan dengan menggunakan jenis penelitian deskriptif kuantitatif. Duli (2019:3) menjelaskan bahwa penelitian kuantitatif merupakan kegiatan pengumpulan, pengolahan, analisis, dan penyajian data berdasarkan jumlah atau banyaknya yang dilakukan secara objektif untuk memecahkan suatu persoalan atau menguji suatu hipotesis untuk mengembangkan prinsip-prinsip umum.

Penelitian ini dilakukan dengan menggunakan instrumen angket. Menurut Riduwan (2010:71) angket adalah daftar pertanyaan yang diberikan kepada orang lain yang bersedia untuk memberikan respon sesuai dengan permintaan pengguna. Angket yang digunakan dalam penelitian ini ialah angket bentuk skala yakni serangkaian strata, level atau nilai yang menggambarkan variasi derajat sesuatu. Pada penelitian ini, dengan menetapkan secara spesifik variabel penelitian. Variabel dijadikan sebagai indikator yang dapat di ukur dengan 5 alternatif jawaban diantaranya: Selalu (SL), Sering (SR), Kadang-kadang (KD), Jarang (JR), dan Tidak pernah (TP). Pernyataan disusun secara sistematis, kemudian diberikan kepada responden untuk diisi oleh responden. Setiap pernyataan diberikan penanda pada salah satu jawaban yang telah disediakan, dan responden memilih salah satu alternatif jawaban, berupa pernyataan positif serta pernyataan negatif. Masing-masing skor jawaban positif responden adalah 5,4,3,2,1 dan untuk skor item negatif jawaban responden adalah 1,2,3,4,5.

Populasi penelitian berjumlah 280 orang mahasiswa, teknik pengambilan sampel yaitu dengan menggunakan teknik proposional random sampling yaitu pengambilan sampel secara acak dengan jumlah sampel sebanyak 164 orang mahasiswa (Yusuf. 2005:191).

Sugiyono (2013:147) mengemukakan bahwa teknik analisis data merupakan sebuah cara yang digunakan untuk menguraikan keterangan dari data yang diperoleh agar data tersebut dapat dipahami oleh peneliti dan pihak lain yang ingin mengetahui hasil penelitian”.

Teknik analisis data pada penelitian kuantitatif memakai statistik deskriptif, yang artinya statistik yang dipergunakan buat menganalisis data menggunakan cara mendeskripsikan atau menggambarkan data yang sudah terkumpul sebagaimana adanya tanpa bermaksud membentuk konklusi yang berlaku 
buat awam atau generalisasi. Analisis data dilakukan sesudah data terkumpul melalui angket. Data yang terkumpul melalui angket dideskripsikan berupa tabel, grafik, frekuensi, rata-rata dan lain sebagainya.

Hasil jawaban pertanyaan dari masalah penelitian yang peneliti temukan dapat dilihat melalui statistik deskriptif untuk mendeskripsikan data tentang skor responden mengenai permasalahan penyesuaian sosial. Penghitung presentase masing-masing frekuensi yang diperoleh, peneliti menggunakan analisis data dengan menggunakan bantuan Microsoft Excel 2007. Teknik analisis data yang digunakan adalah presentase untuk mengungkapkan aspek yang diteliti.

\section{HASIL DAN PEMBAHASAN}

Hasil dari penelitian ini menemukan bahwa Self control mahasiswa Bimbingan dan Konseling dalam mengatasi prokrastinasi akademik di STKIP PGRI Sumatera Barat berada pada kategori tinggi dengan persentase $42,07 \%$. Selanjutnya berdasarkan data yang dikumpulkan mengenai profil Self control mahasiswa Bimbingan dan Konseling dalam mengatasi prokrastinasi akademik di STKIP PGRI Sumatera Barat akan dibahas secara khusus :

1. Self Control Perilaku (Behavioral Control) Mahasiswa dalam Mengatasi Prokrastinasi Akademik Dilihat dari:

a. Kemampuan Mengontrol Perilaku

Tabel 1. Distribusi Frekuensi dan Kategori Skor Profil Self Control Perilaku (Behavioral Control) Mahasiswa dalam Mengatasi Prokrastinasi Akademik Dilihat dari Kemampuan Mengontrol Perilaku

\begin{tabular}{|c|c|c|c|}
\hline Klarifikasi & Kategori & F & $\%$ \\
\hline $37-45$ & Sangat Tinggi & 60 & 36,59 \\
\hline $30-36$ & Tinggi & 70 & 42,68 \\
\hline $23-29$ & Cukup tinggi & 33 & 20,12 \\
\hline $16-22$ & Rendah & 1 & 0,61 \\
\hline $9--15$ & Sangat Rendah & 0 & 0,00 \\
\hline \multicolumn{5}{|}{$\mathbf{\Sigma}$} & $\mathbf{1 6 4}$ & $\mathbf{1 0 0 , 0 0}$ \\
\hline
\end{tabular}

Hasil penelitian menunjukan bahwa self control perilaku (behavioral control) mahasiswa Bimbingan dan Konseling dalam mengatasi prokrastinasi akademik di STKIP PGRI Sumatera Barat dilihat dari kemampuan mahasiswa dalam mengontrol perilaku berada pada kategori yang tinggi dengan persentase yang didapat yaitu sebesar 42,68\%, dapat digambarkan bahwasanya sebagian besar mahasiswa tersebut mempunyai kemampuan yang tinggi untuk dapat mengontrol perilakunya pada saat sedang mengikuti proses perkuliahan yang dijalaninya.

Berdasarkan hasil penelitian ini, bentuk dari kemampuan mengontrol perilaku yang tinggi adalah mahasiswa yang mampu untuk dapat mengendalikan perilakunya pada proses mereka dalam menjalani masa perkuliahan, seperti mahasiswa yang dapat mengikuti perkuliahan dengan tepat waktu, mahasiswa yang bisa mengerjakan pekerjaan perkuliahannya dengan tepat waktu, mahasiswa yang dapat membagi waktunya antara kegiatan akademik dengan non akademik, dan mahasiswa yang mampu untuk menempatkan prilakunya sesuai dengan situasi dan kondisi.

Tingkah laku dan kebiasaan belajar mahasiswa erat kaitannya terhadap penggunaan waktu yang baik buat belajar juga aktivitas lainnya. Hanifah (Atik \& Sutrisno, 2016:28) berpendapat bahwasanya belajar yang efisien bisa diraih apabila memakai strategi yang sesuai dan tepat, yaitu dengan digunakannya pengaturan waktu yang baik pada mengikuti proses perkuliahan, belajar di rumah, berkelompok maupun dalam mengerjakan ujian. Sikap belajar yang baik bisa diwujudkan jika mahasiswa itu sadar pada tanggung jawab ia sebagai mahasiswa, sehingga mereka bisa membagikan waktu mereka dengan baik antara belajar dengan aktivitas di luar belajar.

Menurut Averill (Ghufron dan Rini, 2010:29) kemampuan individu dalam mengendalikan perilakunya yaitu bagaimana cara individu dalam menentukan siapa yang mengendalikan situasi atau keadaan, apakah 
dirinya sendiri atau aturan perilaku dengan menggunakan kemampuan dirinya. Oleh karena itu, hal inilah yang dapat menentukan atas perilaku yang dimunculkan oleh mahasiwa tersebut dalam menindak suatu pekerjaan yang akan ia lakukan.

Berdasarkan pendapat di atas dapat disimpulkan bahwa kemampuan mengontrol perilaku merupakan kemampuan individu dalam mengendalikan tingkah lakunya, apakah perilaku yang ditimbulkan merupakan keinginannya sendiri atau ada aturan yang harus ia patuhi untuk berperilaku seperti aturan tersebut. Kondisi inilah yang mengharuskan individu untuk memilih dan mengendalikan perilaku yang akan ditampilkan.

b. Kemampuan Mengontrol Stimulus

Tabel 2. Distribusi Frekuensi dan Kategori Skor Profil Self Control Perilaku (Behavioral Control) Mahasiswa dalam Mengatasi Prokrastinasi Akademik Dilihat dari Kemampuan Mengontrol Stimulus

\begin{tabular}{|c|c|c|c|}
\hline Klarifikasi & Kategori & F & $\%$ \\
\hline $31-36$ & Sangat Tinggi & 9 & 5,49 \\
\hline $25-30$ & Tinggi & 60 & 36,59 \\
\hline $19-24$ & Cukup tinggi & 63 & 38,41 \\
\hline $13-18$ & Rendah & 26 & 15,85 \\
\hline $7--12$ & Sangat Rendah & 6 & 3,66 \\
\hline \multicolumn{5}{|r}{} & 164 & $\mathbf{1 0 0 , 0 0}$ \\
\hline
\end{tabular}

Hasil penelitian menunjukan bahwa self control perilaku (behavioral control) mahasiswa Bimbingan dan Konseling dalam mengatasi prokrastinasi akademik di STKIP PGRI Sumatera Barat dilihat dari kemampuan mengontrol stimulus berada pada kategori cukup tinggi dengan persentase $38,41 \%$, dapat digambarkan bahwasanya pada sebagian besar mahasiswa tersebut mempunyai kemampuan yang cukup tinggi dalam mengontrol stimulus pada saat menjalani proses perkuliahan.

Berdasarkan hasil penelitian ini, bentuk dari kemampuan mengontrol stimulus mahasiswa yang cukup tinggi adalah mahasiswa dapat melawan rasa malas ketika hendak mengerjakan tugas perkuliahan. Mahasiswa dapat mengontrol kondisi perasaan dirinya ketika mengerjakan tugas perkuliahan. Mahasiswa tidak menyerah dan menunda ketika mendapatkan hambatan dalam menyelesaikan tugas perkuliahan. Mahasiswa dapat untuk tidak memanjakan dirinya ketika ingin mengerjakan tugas perkuliahan, maksudnya yaitu mahasiswa tersebut mampu untuk menagkis dan meredam segala bentuk yang membuat dirinya dapat menunda waktu dalam mengerjakan tugas perkuliahannya.

Secara umum orang yang mempunyai kontrol diri yang tinggi akan menggunakan waktu dengan tepat dan mengarah pada perilaku yang lebih diperlukan. Mahasiswa yang mempunyai kewajiban untuk mengikuti arahan dalam perkuliahan, jika memiliki kontrol diri yang tinggi, mereka akan bisa memandu, mengarahkan serta mengatur sikap. Mereka bisa mengatur stimulus sebagai akibatnya bisa untuk menyesuaikan perilakunya pada hal-hal yang lebih menunjang penyelesaian tugas dan kewajiban dalam perkuliahan. Sehingga ia akan sesegera mungkin menyelesaikan tugas dan kewajiban tanpa menunda-nundanya (Noor \& Hervi, 2011:67).

Menurut Averill (Ghufron dan Rini, 2010:29) kemampuan individu dalam mengontrol stimulus yaitu bagaimana cara individu dalam mengetahui bagaimana dan kapan sesuatu ransangan yang tak diinginkan dihadapi. Hal yang bisa digunakan mahasiswa agar dapat mencegah dan menghilangkan stimulus dengan meletakkan jarak waktu diantara susunan stimulus yang sedang berlangsung dan memberhentikan stimulus sebelum waktunya berakhir serta menetapkan intensitasnya.

Berdasarkan pendapat di atas dapat disimpulkan bahwa mahasiswa yang dapat menerapkan cara untuk meredam terjadinya stimulus yang tidak ingin dikehendaki yang mana dapat melalaikan waktu dalam penyelesaian pekerjaannya, maka akan dapat mengerjakan pekerjaannya dengan selesai dan tepat waktu tanpa adanya tindakan untuk melakukan prokrastinasi. 
2. Self Control Kognitif (Cognitif Control) Mahasiswa dalam Mengatasi Prokrastinasi Akademik Dilihat dari:

a. Kemampuan Mengantisipasi Suatu Peristiwa atau Kejadian

Tabel 8. Distribusi Frekuensi dan Kategori Skor Profil Self Control Kognitif (Cognitif Control) Mahasiswa dalam Mengatasi Prokrastinasi Akademik Dilihat dari Kemampuan Mengantisipasi Suatu Peristiwa atau Kejadian

\begin{tabular}{|c|c|c|c|}
\hline Klarifikasi & Kategori & $\mathbf{F}$ & $\%$ \\
\hline $37-45$ & Sangat Tinggi & 52 & 31,71 \\
\hline $30-36$ & Tinggi & 60 & 36,59 \\
\hline $23-29$ & Cukup tinggi & 50 & 30,49 \\
\hline $16-22$ & Rendah & 2 & 1,22 \\
\hline $9--15$ & Sangat Rendah & 0 & 0,00 \\
\hline & $\Sigma$ & 164 & 100,00 \\
\hline
\end{tabular}

Hasil penelitian menunjukan bahwa self control kognitif (cognitif control) mahasiswa Bimbingan dan Konseling dalam mengatasi prokrastinasi akademik di STKIP PGRI Sumatera Barat dilihat dari kemampuan mengantisipasi suatu peristiwa atau kejadian berada pada kategori tinggi dengan persentasee $36,59 \%$, dapat digambarkan bahwasanya pada sebagian besar mahasiswa mempunyai kemampuan yang tinggi dalam mengantisipasi suatu peristiwa atau kejadian.

Berdasarkan hasil penelitian bentuk kemampuan yang tinggi dalam mengantisipasi suatu peristiwa atau kejadian yang dilakukan oleh mahasiswa adalah mahasiswa yang berusaha untuk dapat menyelesaikan tugas perkuliahan secepatnya tanpa memperpanjang waktu dalam penyelesaiannya. Mahasiswa dapat mempersiapkan segala sesuatu untuk mengikuti perkuliahan, seperti mempersiapkan hal-hal yang dibutuhkan sewaktu perkuliahan, agar tidak memakan waktu untuk mencari sesuatu yang dibutuhkan dalam mengikuti perkuliahan. Mahasiswa tidak menyia-nyiakan rentang tempo yang diberikan Dosen dalam mengumpulkan pekerjaan, pada akhirnya dapat mengantisipasi terjadinya keterlambatan dalam mengumpulkan tugas perkuliahan. Mahasiswa dapat memprediksi hal-hal yang mungkin dapat menyebabkan ia untuk terlambat dalam mengikuti perkuliahan, seperti memilih jalan alternatif yang memungkinkan ia untuk terhindar dari kemacetan yang dapat membuatnya terlambat dalam mengikuti perkuliahan.

Menurut Salmi, dkk (Thara \& Ibrahim, 2019:6) kemampuan seseorang dalam mengantisipasi suatu peristiwa atau kejadian akan dapat mempengaruhi seseorang dalam memimpin dirinya, dimana hal tersebut dapat diberitahukan menggunakan keahlian dalam mengaitkan diri dengan lingkungan secara lebih responsif, menyesuaikan diri, dan kemampuan bebas untuk memilih secara obyektif.

Menurut Averill (Ghufron dan Rini, 2010:29) kemampuan individu dalam mengantisipasi suatu peristiwa atau kejadian yaitu individu menggunakan informasi yang dimilikinya perihal sesuatu kondisi yang dapat merugikannya, pribadi tersebut dapat mengantisipasi keadaan itu menggunakan berbagai pertimbangan.

Berdasarkan pendapat di atas dapat disimpulkan bahwa dalam kemampuan mengantisipasi ini, mahasiswa yang dapat memikirkan dan mempertimbangkan segala sesuatu untuk memulai perkerjaannya, maka tidak mungkin terjadinya perihal yang merugikan yang dapat menyebabkan terjadinya keterlambatan sehingga dapat terantisipasi oleh mahasiswa tersebut.

b. Kemampuan Menafsirkan Peristiwa atau Kejadian 
Tabel 4. Distribusi Frekuensi dan Kategori Skor Profil Self Control Kognitif (Cognitif Control) Mahasiswa dalam Mengatasi Prokrastinasi Akademik Dilihat dari Kemampuan Menafsirkan Peristiwa atau Kejadian

\begin{tabular}{|c|c|c|c|}
\hline Klarifikasi & Kategori & F & \% \\
\hline $31-36$ & Sangat Tinggi & 23 & 14,02 \\
\hline $25-30$ & Tinggi & 80 & 48,78 \\
\hline $19-24$ & Cukup tinggi & 41 & 25,00 \\
\hline $13-18$ & Rendah & 20 & 12,20 \\
\hline $7--12$ & Sangat Rendah & 0 & 0,00 \\
\hline \multicolumn{5}{|}{$\mathbf{\Sigma}$} & $\mathbf{1 6 4}$ & $\mathbf{1 0 0 , 0 0}$ \\
\hline
\end{tabular}

Hasil penelitian menunjukan bahwa self control kognitif (cognitif control) mahasiswa Bimbingan dan Konseling dalam mengatasi prokrastinasi akademik di STKIP PGRI Sumatera Barat dilihat dari kemampuan menafsirkan peristiwa atau kejadian berada pada kategori tinggi dengan persentase $48,78 \%$, dapat digambarkan bahwasanya sebagian besar mahasiswa mempunyai kemampuan yang tinggi dalam menafsirkan peristiwa atau kejadian pada saat mengikuti perkuliahan.

Berdasarkan hasil penelitian bentuk kemampuan dalam menafsirkan peristiwa atau kejadian yang tinggi adalah mahasiswa dapat mengambil pelajaran setelah ia terlambat ataupun gagal dalam menyelesaikan dan mengumpulkan tugas perkuliahan, agar kedepannya tidak terlambat lagi dalam menyelesaikan dan mengumpulkan tugas. Mahasiswa dapat memahami hal-hal yang dapat membuatnya terlambat dalam mengikuti perkuliahan ataupun mengumpulkan tugas perkuliahan. Mahasiswa bisa menyadari terhadap tindakannya yang dapat mengakibatkan terjadinya prokrastinasi akademik.

Menurut Averill (Ghufron dan Rini, 2010:29) kemampuan individu dalam menafsirkan peristiwa atau kejadian yaitu individu berusaha untuk menilai serta menafsirkan sesuatu kondisi atau peristiwa menggunakan cara memerhatikan segi-segi positif secara subjektif. Lalu Mudjiran, dkk
(Thara \& Ibrahim, 2019:6) juga menyampaikan bahwasanya berpikir positif pada maksud untuk mencoba memerhatikan suatu peristiwa atau kejadian pada bagian positifnya.

Berdasarkan pendapat di atas dapat disimpulkan bahwa mahasiswa yang dapat mempelajari semua suatu yang telah dilaluinya menggunakan cara untuk mengambil perihal yang positif yang dapat diterapkan kedepannya, agar tidak terjadinya kesalahan yang sama yang dapat terulang kembali. Prokrastinasi akan dapat terulang kembali jika mahasiswa tersebut tidak memerhatikan dan mempelajari hal-hal yang menyebabkan ia untuk melakukan tindakan prokrastinasi akademik.

3. Self Control Keputusan (Decision Control) Mahasiswa dalam Mengatasi Prokrastinasi Akademik Dilihat dari Kemampuan Mengambil Keputusan

Tabel 5. Distribusi Frekuensi dan Kategori Skor Profil Self Control Keputusan (Decision Control) Mahasiswa dalam Mengatasi Prokrastinasi Akademik Dilihat dari Kemampuan Mengambil Keputusan

\begin{tabular}{|c|c|c|c|}
\hline Klarifikasi & Kategori & $\mathbf{F}$ & \% \\
\hline $37-45$ & Sangat Tinggi & 38 & 23,17 \\
\hline $30-36$ & Tinggi & 60 & 36,59 \\
\hline $23-29$ & Cukup tinggi & 62 & 37,80 \\
\hline $16-22$ & Rendah & 4 & 2,44 \\
\hline $9--15$ & Sangat Rendah & 0 & 0,00 \\
\hline \multicolumn{5}{|}{$\mathbf{\Sigma}$} & $\mathbf{1 6 4}$ & $\mathbf{1 0 0 , 0 0}$ \\
\hline
\end{tabular}

Hasil penelitian menunjukan bahwa self control keputusan (decision control) mahasiswa Bimbingan dan Konseling dalam mengatasi prokrastinasi akademik di STKIP PGRI Sumatera Barat dilihat dari kemampuan mengambil keputusan berada pada kategori cukup tinggi dengan persentase $37,80 \%$, dapat digambarkan bahwasanya sebagian besar mahasiswa mempunyai kemampuan yang cukup tinggi dalam mengambil keputusan.

Berdasarkan hasil penelitian sebagian mahasiswa yang mengambil keputusan cenderung tergesa-gesa. Hal itu ditimbulkan bahwasanya keputusan yang diambil tidak 
dipikirkan lagi bagaimana efek kedepan nantinya. Tindakan ini bisa terjadi dikarenakam mahasiswa belum sanggup dalam menunjuk tindakan yang dipercayai berdasarkan nilai-nilai yang berlaku, karena untuk menentukan tindakan seseorang haruslah membutuhkan pertimbangan yang masak (Eka Putri, dkk. 2018:106).

Menurut Averill (Ghufron dan Rini, 2010:29) kemampuan individu dalam mengambil keputusan yaitu kemampuan dalam memilih hasil atau suatu tindakan berdasarkan pada sesuatu yang diyakini atau disetujuinya.

Bentuk dari kemampuan yang cukup tinggi dalam mengambil keputusan adalah mahasiswa memulai mengerjakan tugas berdasarkan menggunakan jadwal yang sudah diputuskan. Mahasiswa dapat memutuskan sesuatu yang menurutnya itu adalah hal yang tepat. Mahasiswa memiliki pertimbangan disetiap perencanaan dalam mengerjakan tugas perkuliahan. Mahasiswa memiliki rencana disetiap keputusan yang diambilnya.

\section{KESIMPULAN}

Berdasarkan analisis data dan pembahasan, dapat diambil kesimpulan mengenai profil self control mahasiswa Bimbingan dan Konseling dalam mengatasi prokrastinasi akademik di STKIP PGRI Sumatera Barat. Temuan penelitian ini dapat disimpulkan sebagai berikut.

1. Profil self control kognitif (Behavioral control) mahasiswa Bimbingan dan Konseling dalam mengatasi prokrastinasi akademik di STKIP PGRI Sumatera Barat dilihat dari:

a. kemampuan mengontrol perilaku berada pada kategori tinggi. Artinya mahasiswa memiliki kemampuan mengontrol perilaku yang tinggi dalam mengatasi prokrastinasi akademik.

b. kemampuan mengontrol stimulus berada pada kategori cukup tinggi. Artinya mahasiswa memiliki kemampuan mengontrol stimulus yang cukup tinggi dalam mengatasi prokrastinasi akademik.

2. Profil self control Kognitif (Cognitif control) mahasiswa Bimbingan dan Konseling dalam mengatasi prokrastinasi akademik di STKIP PGRI Sumatera Barat dilihat dari:

a. kemampuan mengantisipasi suatu peristiwa atau kejadian berada pada kategori tinggi. Artinya mahasiswa memiliki kemampuan mengantisipasi suatu peristiwa atau kejadian yang tinggi dalam mengatasi prokrastinasi akademik.

b. kemampuan menafsirkan peristiwa atau kejadian berada pada kategori tinggi. Artinya mahasiswa memiliki kemampuan menafsirkan peristiwa atau kejadian yang tinggi dalam mengatasi prokrastinasi akademik.

3. Profil self control keputusan (decision control) mahasiswa Bimbingan dan Konseling dalam mengatasi prokrastinasi akademik di STKIP PGRI Sumatera Barat dilihat dari kemampuan mengambil keputusan berada pada kategori cukup tinggi. Artinya mahasiswa memiliki kemampuan mengambil keputusan yang cukup tinggi dalam mengatasi prokrastinasi akademik.

\section{REFERENSI}

Ansori, Miksan. 2020. Dimensi HAM dalam Undang-undang Sistem Pendidikan Nasional Nomor 20 Tahun 2003. IAIFA PRESS.

Anwar, Muhammad. 2015. Filsafat Pendidikan. Jakarta: Kencana.

Atik Rokhana, Linda \& Sutrisno, Sugeng. 2016. Pengaruh Kecerdasan Emosional, Perilaku Belajar dan Minat Belajar Terhadap Tingkat Pemahaman Akuntansi. (Studi Empiris Pada Mahasiswa Akuntansi Fakultas Ekonomika Dan Bisnis UNTAG Semarang). Media Ekonomi dan Manajemen. Vol. 31 No. 1. ISSN : 085-1442.

Balkis Murat \& Duru Erdinc. 2017. “Gender Differences in the Relationship between Academic Procrastination, Satifaction With Academic Life and Academic Performance". Electronic Journal Of Research in Educational 
Psychology, vol 15, no 1. E-ISSN 1696-2095.

Duli, Nikolaus. 2019. Metodologi Penelitian Kuantitatif: Beberapa Konsep Dasar untuk Penulisan Skripsi \& Analisis Data dengan SPSS. Yogyakarta: Deepublish.

Endrianto, Catriyona. 2014. Hubungan Antara Self Control dan Prokrastinasi Akademik Berdasarkan TMT. Calyptra: Jurnal Ilmiah Mahasiswa Universitas Surabaya, Vol. 3; No. 1.

Eka Putri, Yola dkk. 2018. Self-Control of Students in Using the Internet. Univeritas Negeri Padang. Konselor. Volume 7 Number 3. ISSN: Print 1412-9760 _ Online 2541-5948.

Ghufron, M. Nur \& Rini Risnawita S. 2010. Teori-teori Psikologi. Jogjakarta: Ar-Ruzz Media.

Noor Aini, Aliya \& Hervi Mahardani, Iranita. 2011. Hubungan Antara Kontrol Diri Dengan Prokrastinasi Dalam Menyelesaikan Skripsi Pada Mahasiswa Universitas Muria Kudus. Jurnal Psikologi Pitutur. Volume I, No 2.

Thara Azhari, Dinie \& Ibrahim, Yulidar. 2019. Self-control of Student who tend to Academic Procrastination. Universitas Negeri Padang. Jurnal Neo Konseling. Volume 1 Number 2. ISSN: Print 2657-0556 - Online 2657-0564. DOI: 10.24036/00109kons2019.

Titisari, Haryanti Tri Darmi. 2017. Hubungan antara Penyesuaian diri dan Kontrol diri dengan Perilaku Delikuen pada siswa SMA Muhammadiyah 1, Jombang. Psikodimensia, Vol. 16; No. 2, ISSN online : 2579-6321.

Ursia, Nela Regar, dkk. 2013. "Prokrastinasi Akademik dan Self-Control pada
Mahasiswa Skripsi Fakultas Psikologi Universitas Surabaya". Makara Seri Sosial Humaniora, 17(1): 1-8. DOI: 10.7454/mssh.v17i1.17 